\title{
Public participation for bulk water charge: Paraíba River Basin Committee (Brazil) and Alentejo Hydrographic Region Council (Portugal) cases study
}

\section{A participação pública na construção da cobrança pelo uso da água: os casos do Comitê da Bacia Hidrográfica do rio Paraíba (Brasil) e do Conselho das Regiões Hidrográficas do Alentejo (Portugal)}

\author{
Maria Adriana de Freitas Mágero Ribeiro ${ }^{1}$, Márcia Maria Rios Ribeiro ${ }^{1}$ and Marta Pedro Varanda ${ }^{2}$ \\ ${ }^{1}$ Universidade Federal de Campina Grande, Campina Grande, PB, Brazil \\ ${ }^{2}$ Universidade de Lisboa, Lisboa, Portugal \\ E-mails: drickadefreitas@yahoo.com.br (MAFMR), marcia.ribeiro@ufcg.edu.br (MMRR), marta@iseg.ulisboa.pt (MPV)
}

Received: October 31, 2015 - Revised: March 14, 2016 - Accepted: July 25, 2016

\begin{abstract}
This paper proposes to assess the knowledge and dynamics of Committees/Councils in the discussions and deliberations on the raw water charges in Brazil and in Portugal. The comparison is limited to the evaluation of a Committee and Council and not necessarily reflect the operation of other CBHs, in Brazil, or Councils, in Portugal. It was analyzed the minutes of the meetings of the Paraíba River Basin Committee (CBH-PB) and the Alentejo River Basin Council Region (CRH-Alentejo) as well as interviews with members of the two collective bodies. For the Brazilian case, it appears that CBH-PB members discussed and deliberated on the values and mechanisms for raw water charges. In Portugal, the definition of values and the way of application of the raw water charge (TRH) was held at the central level, without the CRH-Alentejo having the opportunity to argue, not fulfilling its role as a consultative body water management. Water Resources Policies have to gain strength by promoting public participation through discussion formats and being able to engage key stakeholders as well as creating conditions for the development of cooperative relations.
\end{abstract}

Keywords: Public participation; Raw water charges; Stakeholders.

\section{RESUMO}

Neste trabalho propõe-se avaliar o conhecimento e a dinâmica do Comitê/Conselho nas discussões e deliberações sobre a cobrança pelo uso da água, no Brasil, e sobre a Taxa de Recursos Hídricos (TRH), em Portugal. A comparação se limita à avaliação de um Comitê e um Conselho e não reflete, necessariamente, o funcionamento de outros $\mathrm{CBHs}$ (estaduais e federais) e nem de Conselhos. Foram analisadas as atas das reuniões do Comitê da Bacia Hidrográfica do rio Paraíba (CBH-PB) e do Conselho de Recursos Hídricos da Região do Alentejo (CRH-Alentejo) assim como realizadas entrevistas com membros dos dois organismos colegiados. Para o caso brasileiro, verifica-se que os membros do $\mathrm{CBH}-\mathrm{PB}$ discutiram e deliberaram sobre os valores e mecanismos para a cobrança. Em Portugal, a definição dos valores e a forma de aplicação da TRH foi realizada em nível central, sem que o CRH-Alentejo tenha tido possibilidade de se pronunciar, não cumprindo a sua competência de emitir um parecer sobre a TRH, enquanto órgão consultivo de gestão das águas. Faz-se necessário que as Políticas de Recursos Hídricos sejam reforçadas, promovendo a participação pública através de formatos de discussão capazes de envolver os atores chaves e criando condições para o desenvolvimento de relações de cooperação.

Palavras-chave: Participação pública; Cobrança pelo uso da água bruta; Atores sociais. 
Public participation for bulk water charge: Paraíba River Basin Committee (Brazil) and Alentejo Hydrographic Region Council

(Portugal) cases study

\section{INTRODUCTION}

The National Water Resources Policy (PNRH) in Brazil was established by Law 9,433/1997 (BRASIL, 1997), which ensures the water users, civil society and the Government participation. The importance of this envolvement in water basin committees aims to strengthen negotiation and building partnerships (MALHEIROS; PROTA; RINCÓN, 2013).

According to Article 38 of the Federal Law (BRASIL, 1997), the water basin committee is the review body to promote the discussion about the issues related to water resources and to coordinate the activities of the entities involved.

In Paraiba, the State Water Resources Policy (PERH), established by Law 6,308/96 (PARAÍBA, 1996) (altered in 2007 by Law 8,446/07 (PARAÍBA, 2007), to conform to the guidelines of PNRH) provides, in Article 10-B, the proposal of charging mechanisms, and intends to make users responsible and aware of their importance. The proposal suggests the amounts to be charged, on the basis of economic and financial feasibility studies and introduces the impact of any charge on the activities and competitiveness of agribusiness and family farming, as well as on the creation of jobs in the region. Regarding the participation, Article 1 states that the Basin Committees (PARAÍBA, 2007), should be organs of participatory and decentralized management.

European Union has highlighted the public consultation on environmental issues, in policies and documents. This is the case of Aarhus Convention, which guarantees citizen participation in decision making, recognizing public access to information and to justice in environmental matters (FLORIN, 2013). European Union Water Framework Directive (WFD) gives support to public participation in water management, which is also reflected in national legislation. Law 58/2005 adapted into national law Directive 2000/60/EC of the European Union. In Article 12 (PORTUGAL, 2005) of the Portuguese law it is established to the Regional Water Councils, among other powers, to give an opinion on the proposed water resources fee.

Approaches to the water management models are diverse. It is possible to see a highlight to the works that focused on two possibilities of analysis on the subject: the discussion about the legitimacy of these water management models and the government's ability to prepare and implement public policies able to meet the demands of society as highlight some authors (CAMPOS, FRACALANZA, 2010; ABERS et al., 2009).

This research aims to analyze the knowledge of the dynamics of a Committee on the charging for bulk water use (in Brazil) which was discussed and approved by the Basin Committee and the Water Resources Fee (in Portugal) which was promoted and introduced by government (without the participation of the Councils), It seeks to reflect on the role of these collective bodies as decision environments.

\section{PUBLIC PARTICIPATION MODELS}

Public participation can be defined as a process in which individuals, groups and organizations opt for an active role in making decisions that affect them (WANDERSMAN, 1981; ROWE; MARSH; FREWER, 2004; MILANI, 2008; REED, 2008; DUCKER; MORGAN, 2012; DIEGUES, 2012). Dias (2002) adds that participation allows ordinary people to be incorporated into the formulation processes, decision making and implementation of public policies. The different types of participation have been developed to understand the differences between the approaches and the associated methods and to understand the contexts in which they are more appropriate. Among the types of participation, the literature contains: Typology based on different degrees of participation (ARNSTEIN 1969; GOETZ; GAVENTA, 2001; LAWRENCE, 2006); Typology presented as a wheel of participation (DAVIDSON, 1998; ROWE; FREWER, 2000); Typology based on a theoretical framework: rules and/or pragmatic participation (THOMAS, 1993; BEIERLE, 2002) and Typology based on the objectives for which participation is used (TIPPETT; HANDLEY; RAVETZ, 2007). Reed (2008) points out that these types can be used a priori to choose the type of desired participation or can be used post-hoc, to categorize the type of participation that occurred.

Jacobi (2002) comments on the following forms of participation: i) consultative participation - which does not interfere directly in the decision process, which occurs both in the planning phase and/or the definition and implementation of public policies phase. It implies the sharing of decision-making power over management processes and policy formulation; ii) termination/supervisory interest - implies intervention in the course of public life, representing participation in decision making by interfering directly in the modus operandi of public administration. In this type of participation it is assumed that the people are envolved in the control and in the possibility of corrective actions and/or redefinitions of public affairs. In Brazil, the form of participation is more focused on resolving model/inspection, supported by federal law (Law 9,433/1997) (BRASIL, 1997) that determines in one of its principles that the management should be decentralized and participatory. As for water resources management in Portugal, the advisory feature can be considered more present, especially when related to the Councils of Hydrographic Region.

The information discussed in public participation spaces gives those involved the opportunity to express their opinions, and allows public authorities to be aware of such concerns. Several authors emphasize the importance of participation in the definition of water resources management systems (HIRSCH et al., 2010; PERKINS, 2011; GOVERNAT, 2010; HERNÁNDEZ-MORA, BALLESTER, 2011; FRACALANZA; JACOB; EÇA, 2013; ABERS, KECK 2013). Despite the world reference experiences have served to mark the adoption of public participation, there are now different situations involving the institutionalization of this practice, varying formats and levels, presenting results and various difficulties (VASCONCELOS et al., 2011).

According to Participation Ladder Arnstein (1969), the Hydrographic Regional Councils in Portugal are at a level of information and consultation (which allow participants to express themselves). But these conditions do not guarantee that their views are taken into account. However, state River Basin Committees as weel as National River Basin Committees in Brazil can be considered at a higher Partnership step (which allows negotiation and engagement with decision makers).

Literature suggests that the authors oscillate between the indication of the democratic potential, as well as the innovative character of participatory spaces and skepticism about the nature 
of participation in decision making (BISWAS, 2008; PERKINS, 2011; VEIGA; MAGRINI, 2013).

Booth and Halseth (2011) state that since the 1990s the literature on public participation has grown. After 40 years of research and practice, several authors claim that there is still no clear consensus on what "good" public involvement processes are. Although the legislation of some countries ensure participatory approach, there is little discussion about charging for water use and participatory process (BERRETA, 2013). Bulk water charge has a fundamental role in the management of water resources. It is the economic character instrument that aims to control and minimize the shortage by pricing raw water. The charge is often promoted for its incentive effects and can promote two positive consequences: efficiency in the use and efficiency in the distribution of water resources (FREITAS; FRACALANZA, 2012; OECD, 2012; DINAR; POCHAT; ALBIAC, 2015).

\section{BULK WATER CHARGE MODEL}

There are two distinct characteristics in the implementation process of charging bulk water. One of them is the bottom-up where stakeholders discuss the water use charge, a decentralized management model. And in other cases, the collection definition is not open to the examination committee members, featuring a centralized procedure management (top-down).

The role of the representatives in this process is of great importance once they should work for the interests of the people they represent in decision-making. However, this does not necessarily happen in the participatory spaces. Thus, the quality of representation and the broadening of the debate on issues related to water resources are affected.

Perkins (2011) points out that the cases where there is public engagement, sponsored by the government - that the terms and limits of debate are defined in advance by the authorities - are fundamentally more conservative than in the context where the organization is initiated by the community.

In Brazil, participatory institutions appear as one of the major innovations that have occurred in democracy since the 1980s. People are involved in the discussion and in possible corrective actions related to management tools. Decision making is determined by voting, decreasing government control. With the implementation of Federal Law 9,433/1997 (BRASIL, 1997), which established the National Water Resources Policy (PNRH) and created the National Water Resources Management System (SINGREH), there was a big boost to the water management process in Brazil. Federal Law introduced a new paradigm for water management, highlighting the principle of decentralization of water management, with the participation of governments, users and communities in the decision making process. The Brazilian model is innovative once, driven by the concept of sustainable development, it tries to incorporate regional differences in an irregular scenario of water resources distribution and water demand (VEIGA; MAGRINI, 2013). Over the 19 years of the promulgation of the Federal Law, several CBHs were installed in Brazil at the federal level (in river basins under the Union domain; rivers which crosses two or more states) and state level (rivers completely insered in a state). With regard to the charge instrument, the law defines its objectives: to recognize water as an economic good and to give the user an indication of its real value; encouraging the rational use of water and raising funds to finance programs and interventions covered in water resources plans.

In Portugal, Law 58/2005 adapted into national law Directive 2000/60/EC of the European Union (PORTUGAL, 2005). In 2009, following this law, the government has decentralized its management by creating eight river basin districts, in charge of autonomous bodies entitled Regional Hydrographic Administration (ARH). They also created 5 Region Hydrographic Councils, with advisory bodies functions. By Decree-Law 45/94 (PORTUGAL, 1994), the River Basin Councils constituted advisory bodies of regional planning, having been consulted for approval of river basin management plans in 2002. In 2012, law 58/2005 (PORTUGAL, 2005) was revised and the management of water in Portugal was re-centralized, being governed by the (APA - Portuguese Environment Agency). Thus, the administrations of river basin as public institutions with autonomy were extinguished and continued as regional departments of the APA (Decree Law 130/2012) (PORTUGAL, 2012). The River Basin Councils are still mentioned as advisory bodies, however, Article 12 which defined its powers, has been revoked. These councils haven't gathered since 2012. The water management in Portugal did not go through a process of decentralization and, although the river basin councils and water resources plans have been created, decisions remained centralized (VEIGA, 2007). The author also highlights that social involvement and contributions of civil society are considered, provided they do not contradict the interests of the central government. Other times and formatio of public participation and society information in Portugal may be considered essentially passive forms of participation and performed "top down" (DURÃO; VIEGAS PITEIRA; MORAIS, 2012; VASCONCELOS, et al., 2011).

In both studies cases (Brazil and Portugal) bottom-up and top-down characteristics are observed on how to implement bulk water charges. In Brazil, the charge was much discussed in the Paraiba River Committee (CBH-PB), suggesting, changes in state law. However, in Portugal the Water Resources fee was not evaluated by the members of the Alentejo Hydrographic Region (CRH - Alentejo), featuring a form of discussion bottom-up. Management models in some countries, where distinct characteristics regarding the implementation of the charging instrument are observed, are presented as follows.

France waters law dates from 1964 (Law 64,1245/64) (FRANÇA, 1964) having been updated in 1992. In 2003, the 1992 Water Law (FRANÇA, 1992) was revised and influenced by the Water Framework Directive (WFD), promoting greater public involvement in water issues. One of the main features of the French experience is the extensive participation of water users in the discussions. Charging and allocation of water resources are delegated to the river committees. The first years of water management have been marked by tensions and technical and legal impasses relating to charging. Initially the agricultural sector was not fully inserted in the charging process. This segment began its participation in 1986 only, when they decided to join the system, almost symbolically, so that they could benefit from the funding policy of the river basin agencies (MARTINS, 2008; BRUN, 2010, 2014). Veiga (2007) states that the French decentralization 
Public participation for bulk water charge: Paraíba River Basin Committee (Brazil) and Alentejo Hydrographic Region Council

(Portugal) cases study

is considered unfinished, because there is always a demand for better conditions for services transferred from the State to the local authorities, as well as overlapping roles are observed mainly related to economic weaknesses that hinder certain communities fulfill their functions. Yang et al. (2013) add that the French system made some fundamental errors, arising from a series of environmental disasters, during the phases of industrial development, which are expensive and complex to fix.

In Germany the management of water resources has been provided by law since 1957 through the Federal Water Act ("Wasserhaushaltsgesetz") revised in 1976 (ALEMANHA, 1957). The water management plan was reviewed thanks to the implementation of the Water Framework Directive for national law in 2002. Various types of waters plans were introduced in German water law, replaced by the planning established by the water Framework Directive (ALBRECHT, 2013). Based on the "payer-polluter" principle, charging for water use in the German system exists in the form of federal sewer rate established in 1976 and initially applied in 1981. The urban and industrial users who release their effluents into rivers pay fee - collected by states - in order to be encouraged to improve the quality of its effluents (CASTRO, 2012).

The most relevant example of the management of German waters is the experience of the Ruhr River basin. Since the creation of the Ruhr Water Dam Association, it has been established that all members (industrial and commercial enterprises, municipalities and communities) follow the decision taken in assembly, fixing charging for the water use and pollution (BODE; EVERS; ALBRECHT, 2003). According to Reis, Quevedo and Naime (2013), countries like Germany and France stand out in the water management process, due to the civil society action. The authors add that in the German management model the integration between industries, municipalities and other members of civil society is possible, ensuring the participation of all segments interested in the decision process.

The management models associated with the participation of interested parties are able to enhance both the level of involvement of the collegiate bodies and the quality of environmental decisions, reflecting the different forms of participation in issues related to charging for water use.

In the examples cited above, countries like France and Germany have a more decentralized management model, capable of conducting discussions about the management tools specifically charging for the use of water, so that those stakeholders may give feedback and suggest improvements the decision-making process.

According to Avritzer (2012) literature has a study variety that is able to describe the genealogy and the implementation process of participatory structures. However, few attempts to compare and evaluate the operation of these participatory mechanisms in different political and institutional contexts were done, as well as to analyze the impact on public policy.

\section{MATERIAL AND METHODS}

This study is based on different methodologies such as interviews, observation and document analysis (minutes, reports, attendance lists). The article will focus on the analysis of the Alentejo Hydrographic Region Council during its operating period (20092012) (AGÊNCIA PORTUGUESA DO AMBIENTE, 2013) and of meetings minutes of the Paraiba River Committee (2007 to 2013) (AESA, 2011), - some minutes were made available through personal contact - and the analysis of policy-making documents, such as Hydrographic Regional Management Plan (PGRH) and the State Water Resources Plan (PERH-PB).

The analysis of the minutes consisted in the identification and categorization of all interventions that directors/members have made in the meetings, such as presentations, proposals, requests for information, answers/explanations, comments, and/or protocol. In the $\mathrm{CRH}$-Alentejo, who defined the composition was the government, itemizing each participant in $\mathrm{CRH}$, including the various sectors related to water management (Decree 394/2008) (PORTUGAL, 2008a). One way found to systematize the representatives was to identify the categories of stakeholder who have made interventions in the meetings, which were divided as follows: Central Administration (AC); Local Administration (AL); Scientific-Technical Sector (TC); Economic Activities (AE); Civil Society (SC). For the Brazilian case, the segments are divided according to the respective regulations: Public Power (PP); Civil Society (SC), Water Users (AU).

A representation analysis was not carried out in the segments, only participant observation. Although the municipal government represents the local society in general, it had little contribution to meeting discussions and to the dissemination of the studied collective bodies actions.

The issues referred to in the meetings were distributed as follows: risk management (prevention and mitigation of the effects of pollution and drought protection) and recovery of water resources; monitoring, research and knowledge; participation, communication and governance; organizational processes in CRH; economic and financial framework; institutional and regulatory framework; water quality; quantity of water. Data collection on the functioning of CRH-Alentejo and of CBH-Paraíba and on their relations with other bodies and political processes may have restrictions because the minutes are sources of information that may have limitations.

This analysis was also based on both formal talks with members of the $\mathrm{CBH}-\mathrm{PB}$ and of the $\mathrm{CRH}$-Alentejo and on participant observation at meetings of the CBH-PB. In CRH-Alentejo and $\mathrm{CBH}-\mathrm{PB}$ interviews were conducted directed to the segments that make up the two bodies. For the CRH-Alentejo, 20 members were interviewed, distributed among teachers, technicians of the local administration, consultants and segment of economic activities. In CBH-PB, 27 members were interviewed (distributed among civil society, water users and public authorities). $\mathrm{CBH}-\mathrm{PB}$ and $\mathrm{CRH}$-Alentejo attendance lists were also tools of analysis of this reseacrh. In the period studied for the $\mathrm{CBH}-\mathrm{PB}$ seven meetings happened. Only five meetings attendance lists were available. The lists had information on the institutions that are part of the $\mathrm{CBH}$, their representatives and their signatures.

\section{Study area}

Paraiba River Basin and Alentejo Hydrographic Region

The state of Paraiba had its State Water Resources Policy approved by Law 6,308/96 (PARAÍBA, 1996). The process to create state committees in Paraiba began in 2000 when work were 
started in watersheds. The participation of committees in the System Management and Water Resources Planning is provided for in Resolution 01/03 (PARAÍBA, 2003) of the State Water Resources Council. The charge for bulk water use was provided for in Article 19 of Law 6,308/96 (PARAÍBA, 1996). However, the charge was only discussed by CBH-PB members in 2007 . The first year of operation of $\mathrm{CBHs}$ was marked by several discussions around bulk water charges, which resulted in the drafting and approval of Resolution 01/2008 (AESA, 2008a) - determining values and criteria for charging for bulk water use.

In 2007, there was an interesting discussion within the State domain river basins committees on the need to revise text of the state law in order to provide compliance with the guidelines of the National Water Resources Policy (PNRH). Among the changes, the explicit consideration of basin committees as members of the state water management system. The current text of Law 6,308/96 (PARAÍBA, 1996) was given, therefore, by Law 8,446/07 (PARAÍBA, 2007). Among the committees that discussed this law was the Paraiba River Basin Committee, object of study of this research. The Paraiba River Basin is divided into four sub-regions: the river basin districts of the Upper, Middle and Lower River Paraiba Course and the sub-basin of the Taperoá River (Figure 1a). According to the Internal Rules of the CBH-PB (AESA, 2008b), it should be composed of sixty (60) members, according to the following distribution among social segments: Civil Society (30\%), water users (40\%), Federal Government (3\%), State Government (7\%) and Municipal Government (20\%). All Paraiba state committee follow the Resolution 05/2000 (National Water Resources Council) (BRASIL, 2000) and Resolution 01/2003 (State Water Resources Council (CERH) (PARAÍBA, 2003) which provide for the creation and vacancies division criteria in committees. According to Resolution 01/2003 (PARAÍBA, 2003) the number of votes of the representatives must meet the following criteria: executive powers of the federal, state and local government: a minimum of twenty percent and up to forty percent of the total votes; number of representatives of civil society and/or civil organizations: at least twenty percent of the total votes and number of representatives of water users: forty percent of the total votes.

The Alentejo region (Figure 1b) has two hydrographic regions to be considered: RH6 (Hydrographic Region 6) and RH7 (Hydrographic Region 7). The CRH Alentejo worked between 2009 and 2012, and is distributed in the following proportion: local administration $39 \%$, central government $19 \%$, representatives of economic activities $23 \%$, technical and scientific sector $16 \%$ and civil society 4\%. Portuguese Hydrographic Region Councils follow the resolution 58/2005 (PORTUGAL, 2005) and Decree 394/2008 (PORTUGAL, 2008b) that establish and approve vacancies on the boards.

\section{RESULTS AND DISCUSSION}

\section{Paraiba River Basin Comittee}

According to attendance list provided in CRH (AGÊNCIA PORTUGUESA DO AMBIENTE, 2013) and CBH-PB (AESA, 2011) - it must be highlighted that some lists were made available through personal contact - the civil society segment achieved the highest rate of participants (40\%), followed by Government (31\%) and water users $(29 \%)$. An average attendance of 24.8 members per meeting was observed, featuring high failure rate, by some sectors. Some meetings of the $\mathrm{CBH}-\mathrm{PB}$ were scheduled, but could not be held for lack of quorum. By criterion an institution is eliminated when its representing member misses two consecutive meetings in the same calendar year without justification accepted by the plenary.

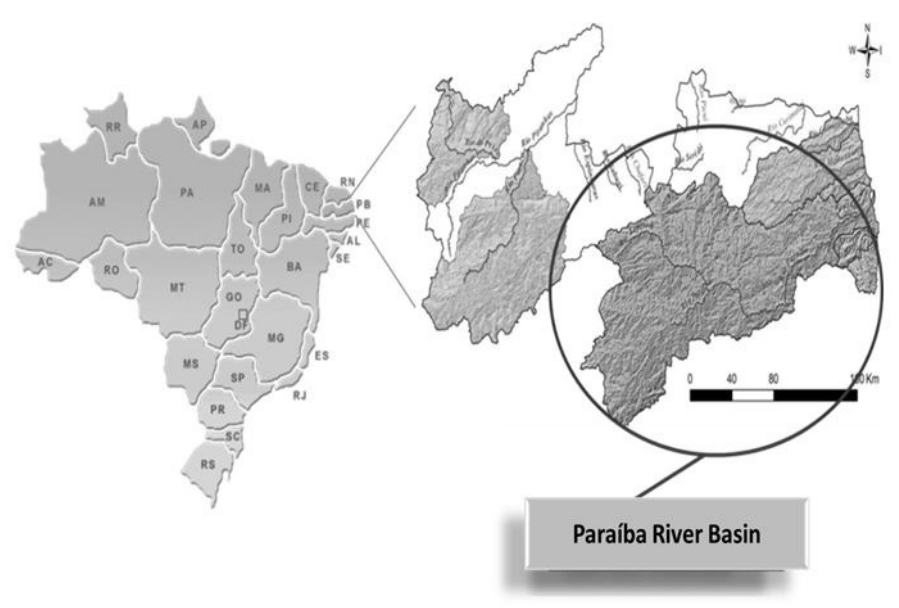

(a)

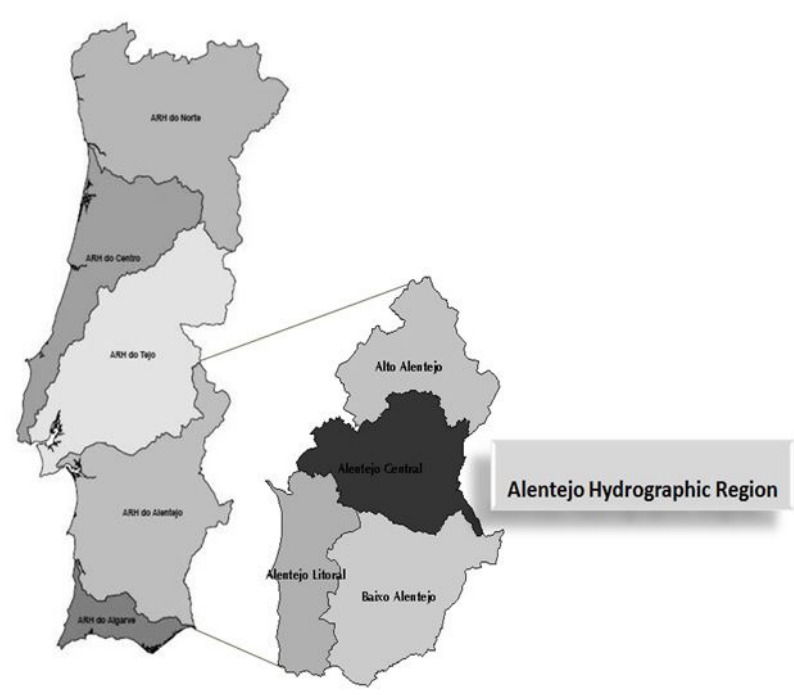

(b)

Figure 1. Paraiba River Basin Location (a) and Alentejo Hydrographic Region Location (b).

Source: Elaborated by the authors. 
Public participation for bulk water charge: Paraíba River Basin Committee (Brazil) and Alentejo Hydrographic Region Council

(Portugal) cases study

Plenary meetings in $\mathrm{CBH}-\mathrm{PB}$ were focused on various topics, in order of frequency: the exemption from charges for the agricultural sector, the collection values and the amount of exemption; the change of the State Water Resources Policy (PERH) by Law 8,446/07 (PARAÍBA, 2007) in order to align the water policy of Paraiba with federal water policy and the proposed revision of the Internal Regime of the $\mathrm{CBH}-\mathrm{PB}$. However, there is no scheduled annual meeting posted on the site (AESA, 2015). In the elaboration of the agenda of the meetings, members may request inclusion of matters to be addressed in CBH-PB. For example, discussions on charging were requested mostly by members of civil society. The second administration of $\mathrm{CBH}-\mathrm{PB}$ exercised his mandate during the period September 2011 to April 2014. In 2014 changes were discussed in the Internal Regime of $\mathrm{CBH}-\mathrm{PB}$, where the following changed: (i) The mandate of the $\mathrm{CBH}-\mathrm{PB}$ members increased from two years to four years; (ii) If there is no quorum for holding of the regular meeting on the first call, there will be reconvening after 30 minutes, in which the meeting will be held with any number of members present in the plenary; (iii) in relation to the Deliberations, they will represent a form of manifestation of the plenary in the case of decision on the matter linked to $\mathrm{CBH}-\mathrm{PB}$ and how to pronounce in manifestation of any kind.

In May 2014 they took possession of the new members that make up the third management of the Paraiba river basin Committee. Generally, the board of CBH -PB is represented by three segments that make up the Committee.

According to Table 1, the interventions are around proposals and clarification of the bulk water charge. Discussions on charging the $\mathrm{CBH}-\mathrm{PB}$ focused on criteria and values for water use. In January 2008, the CBHs approved the respective Resolutions defining how to implement and determining the amounts to be charged in their areas. There is a difference between the values adopted for public supply $\left(\mathrm{R} \$ 0.012 / \mathrm{m}^{3}\right.$ ) and irrigation/other agricultural uses $\left(\mathrm{R} \$ 0.003 / \mathrm{m}^{3}\right)$ - this being scaled value until the third year of the recovery $\left(\mathrm{R} \$ 0.005 / \mathrm{m}^{3}\right)$. The CBHs must meet the provisions of the CERH billing resolution and collection decree. What is decided can not be contemplating (accepted) by the higher court (CERH). In the case of Paraiba, there was no conflict between the $\mathrm{CBH}$ s deliberations and resolution of CERH and nor between CERH with Paraíba State Decree (33,613/2012) (PARAÍBA, 2012).

According to Ribeiro (2011), to meet the principles of decentralized and participatory management, the instrument to charge the use of bulk water needs to be assessed, at the time of installation of state $\mathrm{CBHs}$, by the committees in Paraíba. Based on the deliberations of $\mathrm{CBHs}$, the State Water Resources Council (CERH) (AESA2008a, c, d) approved the charge, through Resolution 07/09 (PARAÍBA, 2010). In 2011 the CERH issued 11/11 Resolution (PARAÍBA, 2011a), redraft and added the devices related to charging for water use. Resolution 12/11 (PARAÍBA, 2011b) was also approved and forwarded to the Chieff of Staff of the Paraíba Government, proposing Decree to regulate state domain raw water use charge. On 14 December 2012, the charge for water use was approved in the State of Paraiba through Decree No. 33,613/2012 (PARAÍBA, 2012). In July 2015, the charge was implemented in Paraiba, initiating the process of collection of funds.

Figure 2 presents members percentage who talked about the charge in $\mathrm{CBH}-\mathrm{PB}$ meetings.

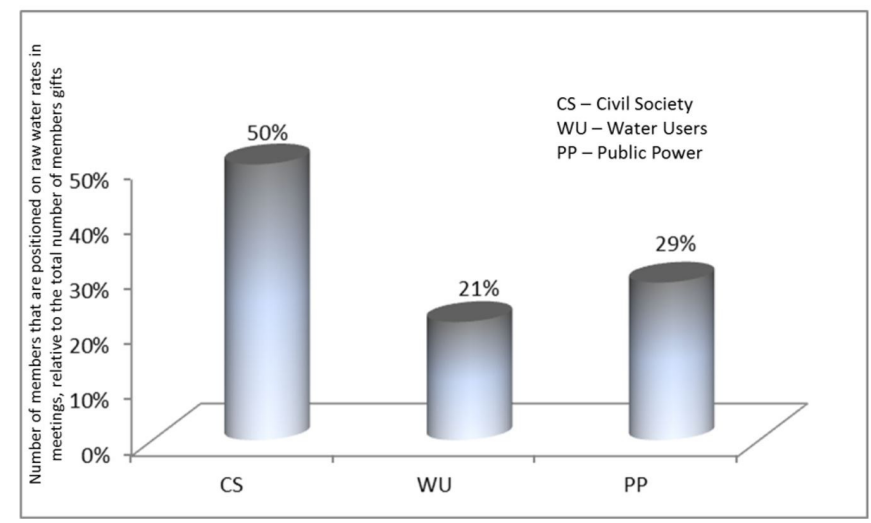

Figure 2. Percentage of members, considering its segment, who discussed bulk water charge in $\mathrm{CBH}-\mathrm{PB}$.

Table 1. Members participation: intervention category/type (CBH-PB) (AESA, 2011).

\begin{tabular}{|c|c|c|c|c|c|c|c|}
\hline \multirow{3}{*}{ Categories } & \multicolumn{7}{|c|}{ CBH-Paraíba } \\
\hline & \multicolumn{2}{|c|}{2007} & \multicolumn{2}{|c|}{2008} & \multirow{2}{*}{$\begin{array}{c}2009 \\
\text { Minute } 1\end{array}$} & \multicolumn{2}{|c|}{2010} \\
\hline & Minute 1 & Minute 2 & Minute 1 & Minute 2 & & Minute 1 & Minute 2 \\
\hline \multirow{3}{*}{$\mathrm{SC}$} & - & Proposals & - & - & - & - & $\begin{array}{c}\text { Information } \\
\text { request; } \\
\text { Comments }\end{array}$ \\
\hline & - & $\begin{array}{l}\text { Responses/ } \\
\text { clarification }\end{array}$ & - & - & - & - & - \\
\hline & - & $\begin{array}{l}\text { Responses/ } \\
\text { clarification }\end{array}$ & - & - & - & - & - \\
\hline PPE & - & Proposals & $\begin{array}{l}\text { Responses/ } \\
\text { clarification / } \\
\text { Presentations }\end{array}$ & - & $\begin{array}{l}\text { Responses/ } \\
\text { clarification / } \\
\text { Presentations }\end{array}$ & - & - \\
\hline PPF & - & - & Proposals & - & - & - & - \\
\hline PPM & - & - & - & - & - & - & - \\
\hline $\mathrm{UA}$ & - & $\begin{array}{l}\text { Information } \\
\text { request; } \\
\text { Comments }\end{array}$ & $\begin{array}{l}\text { Responses/ } \\
\text { clarification / } \\
\text { Presentations }\end{array}$ & - & $\begin{array}{l}\text { Responses/ } \\
\text { clarification / } \\
\text { Presentations }\end{array}$ & - & - \\
\hline
\end{tabular}


The percentages were distributed considering the number of members who have positioned themselves on the collection in the meetings in relation to the total of members present. According to the graph, the segment that was more envolved in discussion was the Civil Society (50\%), followed by Public Power $(29 \%)$ and water users $(21 \%)$.

\section{Alentejo Hydrographic Region Council}

The participation of the segments in the CRH-Alentejo, on average, was distributed as follows: Local Administration, 38\%; Central administration, 23\%; Representatives of Economic Activities, 16\%; Sector Scientific-Technical, 19\% and Civil Society, $4 \%$. For the CRH-Alentejo, the average participation of directors was 33.4 members per meeting (RIBEIRO et al., 2013), corresponding to $58 \%$ of the total membership. As regards the functioning of CRH-Alentejo, the topics discussed were, in order of frequency: the institutional and legal framework; organizational processes $\mathrm{CRH}$; economic and financial framework; monitoring, research and knowledge; water quality; quantity of water; risk management and enhancement of the public domain; participation, communication and governance. For the subjects of these interventions, they focused, in order of frequency on: water quality; quantity of water; monitoring, research and knowledge; institutional and regulatory framework; economic and financial framework; participation, communication and governance; organizational processes $\mathrm{CRH}$; and risk management and exploitation of water resources. TRH (Water Resources Fee) in Portugal is one of the issues on which the CRHs should decide, producing opinions on the subject. However, TRH was set before the CRHs was instituted and, in this case, there is no indication of public participation in formal contexts. There are discussions and proposals for the definition and application of TRH in CRHs. The CRH-Alentejo did not have a public position because it was not consulted on the TRH even with the topic being discussed in the meetings. Table 2 shows the types of interventions in relation to TRH according to different categories of stakeholders in the CRH-Alentejo.
The collection of TRH started in 2009. The representatives of economic activities questioned the process, highlighting the lack of information and participation of users. However, the Regional Hydrographic Administration (ARH) says that TRH was discussed and disclosed. In the last meeting of the Council, in June 15 2012, the Central Administration made explanations regarding TRH stating to that part of the fee goes to the Water Resources Protection Fund, which has worked incipiently. As indicated in Table 2, members who attended most of the discussions involving TRH in CRH-Alentejo were: local administration and representatives of economic activities. The percentage of members who discussed TRH by segment, in meetings of the Council is presented in Figure 3.

The most discussed segments on the topic were Local Government (53\%) and Economic Activities (30\%), followed by the Sector Technical Scientific (14\%) and Central Administration presented $(3 \%)$. The Civil Society segment consists of environmental non-governmental organizations or associations with economic activities related to water, which may have influenced the types of questions, which are more focused on environmental issues. The types of interventions among their members differ widely.

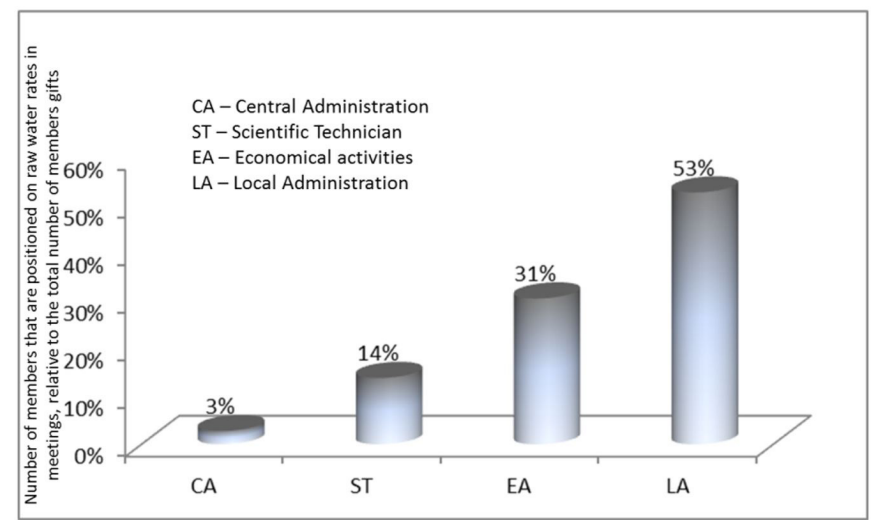

Figure 3. Percentage of members who spoke on TRH (Water Resources Fee) by segment, in CRH - Alentejo.

Table 2. Members participation: intervention category/type (CRH Alentejo) (AGÊNCIA PORTUGUESA DO AMBIENTE, 2013).

\begin{tabular}{|c|c|c|c|c|c|c|c|}
\hline \multirow{3}{*}{ Categories } & \multicolumn{7}{|c|}{ CRH - Alentejo } \\
\hline & \multicolumn{2}{|c|}{2009} & \multirow{2}{*}{$\begin{array}{c}2010 \\
\text { Minute } 4\end{array}$} & \multirow{2}{*}{$\begin{array}{c}2010 \\
\text { Minute } 6\end{array}$} & \multirow{2}{*}{$\begin{array}{c}2011 \\
\text { Minute } 7\end{array}$} & \multirow{2}{*}{$\begin{array}{c}2011 \\
\text { Minute } 8\end{array}$} & \multirow{2}{*}{$\begin{array}{c}2012 \\
\text { Minute } 10\end{array}$} \\
\hline & Minute 1 & Minute 2 & & & & & \\
\hline $\mathrm{AC}$ & - & - & - & - & - & - & $\begin{array}{l}\text { Responses/ } \\
\text { Clarification }\end{array}$ \\
\hline TC & Proposals & - & $\begin{array}{l}\text { Responses/ } \\
\text { Clarification }\end{array}$ & - & $\begin{array}{l}\text { Responses/ } \\
\text { Clarification }\end{array}$ & $\begin{array}{l}\text { Responses/ } \\
\text { Clarification }\end{array}$ & - \\
\hline $\mathrm{AE}$ & $\begin{array}{l}\text { Information } \\
\text { request } \\
\text { Comments } \\
\end{array}$ & $\begin{array}{l}\text { Information } \\
\text { request } \\
\text { Comments } \\
\end{array}$ & $\begin{array}{l}\text { Information } \\
\text { request } \\
\text { Comments } \\
\end{array}$ & - & $\begin{array}{l}\text { Information } \\
\text { request } \\
\text { Comments } \\
\end{array}$ & - & - \\
\hline AL & $\begin{array}{c}\text { Responses/ } \\
\text { Clarification / } \\
\text { Presentations } \\
\end{array}$ & $\begin{array}{l}\text { Responses/ } \\
\text { Clarification }\end{array}$ & $\begin{array}{c}\text { Responses/ } \\
\text { Clarification / } \\
\text { Protocol } \\
\end{array}$ & $\begin{array}{l}\text { Responses/ } \\
\text { Clarification }\end{array}$ & $\begin{array}{l}\text { Responses/ } \\
\text { Clarification }\end{array}$ & $\begin{array}{l}\text { Responses/ } \\
\text { Clarification }\end{array}$ & \\
\hline
\end{tabular}

AC (Central Administration: public power); AL (Local Administration: public power); TC (Scientific Technician); SC (Civil Society); AE (Economical activities: users). Central Administration: all national state bodies; local administration: all local and national state bodies; technical-scientific sector: all representatives of educational and/or research institutions, as well as professional associations; economical activities representatives: economical interests representative company or associations; Civil Society: environmental non-governmental organizations or associations without water economic actities. Source: Elaborated by the authors. In minutes 3,5 and 9 there were no discussions on TRH (Water Resources Fee) during CRH-Alentejo meetings. 
Public participation for bulk water charge: Paraíba River Basin Committee (Brazil) and Alentejo Hydrographic Region Council

(Portugal) cases study

While the representatives of economic activities made requests for information, comments and proposals, local administration intervened to make clarifications and some presentations. The discussion at the central level of TRH without the direct participation of members of Hydrograhic Region Council, brought the CRH-Alentejo some questions as to their application form. Some respondents did not agree with the model that was being drafted without the TRH discussion. One of the points highlighted by the members was in relation to the amounts charged and the scarcity coefficient (applied according to the different climatic conditions). According to Decree-Law 97/2008 (PORTUGAL, 2008c), the base value for the calculation of TRH components is calculated for the following uses: agriculture, fisheries, aquaculture, marine and biogenetic cultures; production of hydroelectric energy; production of thermal power; water systems of public supply and other uses.

The little information passed on by the ARH on the amount raised from the fee were also questioned by respondents as weak point in the meeting, demanding the presentation and the investment of the amount collected. Asked if the ARH Alentejo granted information on TRH in CRH-Alentejo, most respondents said yes. However, little information on the amount transferred was given. The format of meetings and the level and quality of the participation were also emphasized by the members in the interviews. Respondents members contributed with suggestions on how the meetings were conducted, noting that smaller working groups could be put to better use, bringing more quality to the debate with the other members. It requested further dissemination of information on TRH, highlighting the importance of the role of ARH-Alentejo in the processes of public participation. The ARH Alentejo said that TRH impacts in various sectors of activity have been extensively discussed, and that an analysis of its economic impact on different types of farms had already been carried out. In addition to disagree with the definition of process and application of TRH, representatives of economic activities, especially irrigation, questioned the date of implementation of TRH, stating that Portugal was two years ahead the other Europe countries in this aspect, defending the its start in 2010 and not in 2008. Nevertheless, irrigators were among the users who paid TRH for the year 2009, having high expectation on the Protection Fund of Water Resources, one of the main destinations of revenues of TRH, and claiming the increased information on their implementation.

For the CRH - Alentejo, some TRH issues are set out in Water Resources Management Plan (Measures Program), a document that specifies the actions to be undertaken. For $\mathrm{CBH}$ -PB, the Paraíba Water Resources Plan - developed in 2006 - was previously set in relation to the discussions on bulk water charges. As for the Paraiba River Basin Plan, it is outdated.

\section{CONCLUSIONS}

For good water governance, it is necessary that public participation seeks more creative and innovative solutions. Besides government must aim and be able to continue these solutions through the implementation of management tools. Stakeholders evolment in the discussion spaces becomes essential once it demands dialogue and consensus, fundamental characteristics which should be established in participatory processes. The participation of agents should not be used for the representation of interested segments only - as provided by law. The democratic principle of representation should be associated with the legitimacy and representativeness, ensuring that the segments can act with autonomy and coherence.

In Portugal, although the local government sector has shown a higher percentage of participation, its position related to TRH (Water Resources Fee) was directed to provide some clarification, with no further guidance. However, the sector of economic activities showed interest in discussion about TRH, requesting clarification on various aspects of fee. The civil society sector is composed mainly by environmental non-governmental organizations or associations with economic activities related to water. However, due to the low association, meetings had few contributions. Among the highlighted points, TRH formula coefficients calculation was questioned. However, this discussion did not influence the formula of TRH. Once the management model was advisory only, no participation channels was opened for possible changes to TRH. Public participation had not, in fact, any propositional power, and there are no contributions from members of the CRH-Alentejo to TRH.

In Brazil, considering the study case, the municipal government, as well as federal government, could not contribute much to the discussions. The low participation of municipal government (with percentages ranging from $7 \%$ to $10 \%$ ) associated with lack of continuity in the discussions, as well as the scarce amount of gazetted technicians in the municipalities, may have influenced the absence of proposals relating to the collection. In Paraíba, the body responsible for water resources is the State Department of Infrastructure, Water Resources, Environment and Science and Technology (SEIRHMACT), while CAGEPA (Water and Sewerage Company of Paraíba) manages the supply water and sewage.

However, the civil society segment represented by regional associations, technical and educational organizations, non-governmental organizations, among others recognized by CERH (State Water Resources Council), had a strong influence on changes in charge aspects, reflecting significant changes in water management. The participation, when establishing a supervisory/resolutive format allows more information exchange, setting a more active and contributor model of public participation. Unlike the Portuguese case, CBH-PB stood outside the time cycle at the time of elaboration of PERH (Paraíba Water Resources Plan) - in this case it did not count on the participation of state committees of Paraiba. About Water Resources Plans, the Paraíba River Basin Plan is outdated. In 2013, a technical report analyzed Paraíba River Basin Plan, confirming the need to update the Plan. This report was conducted by members of the CBH-PB.

Technical Chambers are part of the organizational structure of the CERH with different characteristics in relation to the themes discussed in the field of water resources management, including the management tools. However, working groups were formed to discuss communication on the committee, bylaws changing proposals and training of members. 
The results of this research reinforces the need for Water Resources Policies to promote public participation through discussion formats, able to involve key stakeholders, and to create conditions for the development of cooperative relations. It is importante to highlight that this necessity applies more to the Portuguese case. The gaps observed in the Portuguese case are reflected by the top-down management model, where rare issues can be inserted to the discussions. For the Brazilian model, adjustments are still necessary in water management, in order to promote more active participation of the members and the strengthening of local bases by social learning.

For future researches, it is suggested to compare the opinion of the segments separately from CBH-Paraíba (Brazilian case) and CRH-Alentejo (Portuguese case).

\section{ACKNOWLEDGEMENTS}

The authors thanks CNPq for the scholarship concession to the first author $\mathrm{PhD}$ - sandwich / Science without Borders program at the Institute of Social Sciences, University of Lisbon, 2013-2014) and the research project (process 484689/2012-6) for funding this research. Thanks also to the opinions of the reviewers that many contributed to the improvement of this article.

\section{REFERENCES}

ABERS, R. N.; FORMIGA-YOHNSSON, R. M.; FRANK, B.; KECK, M. E.; LEMOS, M. C. Inclusão, deliberação e controle: três dimensões de democracia nos comitês e consórcios de bacias hidrográficas no Brasil. Ambiente e Sociedade, v. 12, n. 1, p. 115-132, 2009. http://dx.doi.org/10.1590/S1414-753X2009000100009.

ABERS, R. N.; KECK, M. E. Practical authority: agency and institutional change in Brazilian Water Politics. New York: Oxford University Press, 2013.

AESA - AGÊNCIA EXECUTIVA DE GESTÃO DAS ÁGUAS DO ESTADO DA PARAÍBA. CBH-PB - Comitê da Bacia Hidrográfica do Rio Paraíba. Deliberação $n^{0} 01$, de 26 de fevereiro de 2008. Aprova a implementação da cobrança e determina valores da cobrança pelo uso dos recursos hídricos na Bacia Hidrográfica do rio Paraíba, a partir de 2008 e dá outras providências. João Pessoa, 26 fev. 2008a.

AESA - AGÊNCIA EXECUTIVA DE GESTÃO DAS ÁGUAS DO ESTADO DA PARAÍBA. CBH-PB - Comitê da Bacia Hidrográfica do Rio Paraíba - CBH-PB. Regimento do Comitê da Bacia Hidrográfica do Rio Paraíba. João Pessoa, 2008b.

AESA - AGÊNCIA EXECUTIVA DE GESTÃO DAS ÁGUAS DO ESTADO DA PARAÍBA. CBH-LS - Comitê das Bacias Hidrográficas do Litoral Sul. Deliberação $n^{0} 01$, de 29 de janeiro de 2008. Aprova a implementação da cobrança e determina valores da cobrança pelo uso dos recursos hidricos nas Bacias Hidrográficas do Litoral Sul, a partir de 2008 e dá outras providências. João Pessoa, 29 jan. 2008c.

AESA - AGÊNCIA EXECUTIVA DE GESTÃO DAS ÁGUAS DO ESTADO DA PARAÍBA. CBH-LN - Comitê das Bacias
Hidrográficas do Litoral Norte. Deliberação $n^{0}$ 01, de 27 de março de 2008. Aprova a implementação da cobrança e determina valores da cobrança pelo uso dos recursos hídricos nas Bacias Hidrográficas do Litoral Norte, a partir de 2008 e dá outras providências. João Pessoa, 27 mar. 2008d.

AESA - AGÊNCIA EXECUTIVA DE GESTÃO DAS ÁGUAS DO ESTADO DA PARAÍBA. CBH-PB - Comitê da Bacia Hidrográfica do Rio Paraíba. Atas das reuniões do CBH-PB. João Pessoa, 2011. Available from: <http://www.aesa.pb.gov.br/ comites/paraiba/>. Access on: 12 feb. 2011.

AESA - AGÊNCIA EXECUTIVA DE GESTÃO DAS ÁGUAS DO ESTADO DA PARAÍBA. Calendário de reuniões anuais. João Pessoa, 2015. Available from: <http://www.aesa.pb.gov.br/ comites/paraiba/>. Access on: 15 july 2015.

AGÊNCIA PORTUGUESA DO AMBIENTE. CHR-Alentejo - Conselho de Região Hidrográfica do Alentejo. Atas das reuniões do CHR-Alentejo. 2013. Available from: < http://www.apambiente. pt $/$ index.php? ref $=5 \&$ subref $=637 \&$ sub2ref $=768>$. Access on: 10 may 2013.

ALBRECHT, J. The Europeanization of water law by the water framework directive: a second chance for water planning in Germany. Land Use Policy, v. 30, n. 1, p. 381-391, 2013. http:// dx.doi.org/10.1016/j.landusepol.2012.04.009.

ALEMANHA. WHG - Gesetz zur Ordnung des Wasserhaushalts. Lei Federal de Gerenciamento de Recursos Hidricos, de 27 de julbo de 1957, BGBl I 1957, 1110, 1386, e alterações. 1957.

ARNSTEIN, A. A ladder of citizenship participation. Journal of the American Institute of Planners, v. 26, n. 4, p. 216-224, 1969. http:/ / dx.doi.org/10.1080/01944366908977225.

AVRITZER, L. The different designs of public participation in Brazil: deliberation, power sharing and public ratification. Critical Policy Studies, v. 6, n. 2, p. 113-127, 2012. http://dx.doi.org/10.1 080/19460171.2012.689732.

BEIERLE, T. C. The quality of stakeholder-based decisions. Risk Analysis, v. 22, n. 4, p. 739-749, 2002. http://dx.doi.org/10.1111/02724332.00065. PMid:12224747.

BERRETA, M. S. R. Gestão democrática das águas: os desafios à participação dos agricultores da bacia hidrográfica do Arroio Ribeiro, RS. 2013. 256 f. Tese (Doutorado em Instituto de Geociências) Universidade Federal do Rio Grande do Sul, Porto Alegre, 2013.

BISWAS, A. K. Integrated water resources management: is it working? Water Resources Development, v. 24, n. 1, p. 5-22, 2008. http://dx.doi.org/10.1080/07900620701871718.

BODE, H.; EVERS, P.; ALBRECHT, D. R. Integrated water resources management in the Ruhr River Basin, Germany. Water Science and Technology, v. 47, n. 7-8, p. 81-86, 2003. 
Public participation for bulk water charge: Paraíba River Basin Committee (Brazil) and Alentejo Hydrographic Region Council (Portugal) cases study

BOOTH, A.; HALSETH, G. Why the public thinks natural resources public participation processes fail: a case study of British Columbia communities. Land Use Policy, v. 28, n. 4, p. 898-906, 2011. http://dx.doi.org/10.1016/j.landusepol.2011.03.005.

BRASIL. Ministério do Meio Ambiente dos Recursos Hídricos e da Amazônia Legal. Lei no 9.433, de 08 de janeiro de 1997. Aprova a Política Nacional de Recursos Hídricos. Diário Oficial [da] República Federativa do Brasil, Brasília, DF, 09 jan. 1997.

BRASIL. CNRH - Conselho Nacional de Recursos Hídricos. Resolução n ${ }^{\circ}$ 5, de 10 de abril de 2000. Estabelece diretrizes para a formação e funcionamento dos Comitês de Bacia Hidrográfica. Diário Oficial [da] República Federativa do Brasil, Brasília, DF, 11 abr. 2000.

BRUN, A. France's water policy: the interest and limits of river contracts. In: SCHNEIER-MADANES, G. (Ed.). Globalized water: a question of governance. Netherlands: Springer, 2014. p. 139-147. http://dx.doi.org/10.1007/978-94-007-7323-3_10.

BRUN, A. Les contrats de rivière en France: enjeux, acteurs et territoires. Les Cabiers de Droit, v. 51, n. 3/4, p. 679-704, 2010.

CAMPOS, V. N. O.; FRACALANZA, A. P. Governança das águas no Brasil: conflitos pela apropriação da água e a busca da integração como consenso. Ambiente e Sociedade, v. 13, n. 2, p. 365-382, 2010. http://dx.doi.org/10.1590/S1414-753X2010000200010.

CASTRO, C. N. Gestão das águas: experiências internacional e brasileira. Brasília: IPEA, 2012. Texto para Discussão.

DAVIDSON, S. Spinning the wheel of empowerment. Planning, v. 1262, p. 14-15, 1998. Available from: <http://www.sarkissian.com. au/wendys-blog/professional-posts/the-wheel-of-participation-orempowerment/\#sthash.Qdek1k8K.PKVROXTk.dpuf>. Access on: 10 may 2015.

DIAS, M. R. Entre a representação e a participação política: o debate acerca da institucionalização do orçamento participativo em Poro Alegre. In: MILANI, C.; ARTURI, C.; SOLINÍS, G. (Org.). Democracia e governança mundial: que regulações para o século XXI? Porto Alegre: UFRGS/Unesco, 2002. p. 204-230.

DIEGUES, C. G. A construção da participação social na Gestão das Políticas Públicas: o protagonismo do governo local no Brasil. Administração Pública e Gestão Social, v. 4, n. 4, p. 365-380, 2012. Available from: <http://www.apgs.ufv.br/index.php/apgs/article/ view/115\#.ViQAqH6rTIU>. Access on: 20 sept. 2015.

DINAR, A.; POCHAT, V.; ALBIAC, J. Water pricing experiences and innovations. In: ALBIAC-MURILLO, J.; FAROLFI, S.; SALETH, R. M. (Ed.). Global issues in water policy. Switzerland: Springer International Publishing, 2015. p. 41-61.

DUCKER, D. J.; MORGAN, T. K. K. B. A psychosocial approach to stakeholder participation in environmental problem solving. The case of the contaminated site clean-up at Mapua, New Zealand.
Environmental Management and Sustainable Development, v. 1, n. 2, p. 163-186, 2012. http://dx.doi.org/10.5296/emsd.v1i2.2170.

DURÃO, A. C. R.; VIEGAS PITEIRA, A. J.; MORAIS, M. M. Participação de actores sociais na gestão de bacias hidrográficas: estudo de caso da bacia do rio Ardila. In: CONGRESSO PORTUGUÊS DE SOCIOLOGIA, 7., 2012. Porto. Anais... Porto: Universidade do Porto, 2012. p. 1-15. Available from: <http:// www.aps.pt/vii_congresso/papers/finais/PAP0369_ed.pdf > . Access on: 13 oct. 2013.

FLORIN, M. A. Aspects regarding environmental protection in Romania and EU from juridical perspective. Procedia: Social and Behavioral Sciences, v. 81, p. 27-31, 2013. http://dx.doi. org/10.1016/j.sbspro.2013.06.382.

FRACALANZA, A. P.; JACOB, A. M.; EÇA, R. F. Environmental justice and water resources governance Practices: re-introducing issues of equality to the agenda. Ambiente e Sociedade, v. 16, n. 1, p. 19-38, 2013. http://dx.doi.org/10.1590/S1414-753X2013000100003.

FRANÇA. Loi nº 64-1245 du 16 décembre 1964. Relative au régime et à la répartition des eaux et à la lutte contre leur pollution. Journal Officiel de la République Française. Paris, 18 déc. 1964.

FRANÇA. Loi n 92-3 du 3 janvier 1992. Loi sur l'eau. Journal Officiel de la République Française, Paris, 4 janv. 1992.

FREITAS, S. S.; FRACALANZA, A. P. A Cobrança pelo uso da água como instrumento de valoração ambiental da política de recursos hídricos. In: ENCONTRO NACIONAL DE PESQUISADORES EM GESTÃO SOCIAL, 6., 2012. Juazeiro do Norte. Anais... Juazeiro do Norte: UFC. Available from: < http://anaisenapegs. com.br/2012/>. Access on: 15 aug. 2015.

GOETZ, A.; GAVENTA, J. Bringing citizen voice and client focus into service delivery. Brighton: Institute of Development Studies, 2001. IDS Working Paper. Available from: <http://www.ids.ac.uk/files/ Wp138.pdf>. Access on: 10 apr. 2015.

GOVERNAT. Towards successful participation in European biodiversity and water governance. 2010. Available from: <http:/ /www.governat. eu/files/files/policy_brief_governat_1_2010.pdf>. Access on: 10 sept. 2014.

HERNÁNDEZ-MORA, N.; BALLESTER, A. Public participation and the role of social networks in the implementation of the water framework directive in Spain. Ambientalia - Revista Interdisciplinar de las Ciencias Ambientales, Special issue, p. 1-21, 2011.

HIRSCH, D.; ABRAMI, G.; GIORDANO, R.; LIERSCH, S.; MATIN, N.; SCHLÜTER, M. Participatory research for adaptive water management in a transition country - a case study from Uzbekistan. Ecology and Society, v. 15, n. 3, p. 23, 2010. Available from: <http://www.ecologyandsociety.org/vol15/iss3/art23/>. Access on: 10 aug. 2015. 
JACOBI, P. R. Políticas sociais e ampliação da cidadania. 2. ed. Rio de Janeiro: Editora FGV, 2002.

LAWRENCE, A. No personal motive? Volunteers, biodiversity, and the false dichotomies of participation. Ethics Place and Environment, v. 9, n. 3, p. 279-298, 2006. http://dx.doi.org/10.1080/13668790600893319.

MALHEIROS, T. F.; PROTA, M. G.; RINCÓN, M. A. P. Participação comunitária e implementação dos instrumentos de gestão da água em bacias hidrográficas. Revista Ambiente e Água - An Interdisciplinary Journal of Applied Science, v. 8, n. 1, p. 98-118, 2013.

MARTINS, R. C. Sociologia das águas da governança Francesa. Revista Brasileira de Ciências Sociais, v. 23, n. 67, p. 83-100, 2008. Available from: <http://www.scielo.br/scielo.php?pid=S010269092008000200007\&script=sci_arttext $>$. Access on: 25 sept. 2015.

MILANI, C. R. S. O princípio da participação social na gestão de políticas públicas locais: Uma análise de experiências latino-americanas e européias. Revista de Administração Pública, v. 42, n. 3, p. 551-579, 2008. http://dx.doi.org/10.1590/S0034-76122008000300006.

OECD - ORGANISATION FOR ECONOMIC COOPERATION AND DEVELOPMENT. Financing water resources management. Paris, 2012. Available from: http://www.keepeek.com/ Digital-Asset-management/oecd/environment/a-framework-forfinancing-water-resources-management_9789264179820-en\#.>. Access on: 15 july 2014.

PARAÍBA. Governo do Estado. Lei no 6.308, de 02 de julho de 1996. Institui a Política Estadual de Recursos Hídricos, suas diretrizes e dá outras providências. Diário Oficial do Estado da Paraíba, João Pessoa, PB, 03 jul. 1996.

PARAÍBA. Governo do Estado. CERH - Conselho Estadual de Recursos Hídricos. Resolução n ${ }^{\circ}$ 01, de 06 de agosto de 2003. Trata das diretrizes para formação de Comitês de Bacias. Estabelece diretrizes para a formação, instalação e funcionamento de Comitês de Bacias. Diário Oficial do Estado da Paraíba, João Pessoa, PB, 31 ago. 2003.

PARAÍBA. Governo do Estado. Lei no ${ }^{\circ}$.446, de 28 de dezembro de 2007. Dá nova redação e acrescenta dispositivos à Lei no . 6.308, de 02 de julho de 1996, que institui a Política Estadual de Recursos Hídricos, e determina outras providências. Diário Oficial do Estado da Paraíba, João Pessoa, PB, 29 dez. 2007.

PARAÍBA. Governo da Estado. Secretaria do Meio Ambiente, dos Recursos Hídricos e da Ciência e Tecnologia. CERH - Conselho Estadual de Recursos Hídricos. Resolução no 07, de 16 de julho de 2009. Estabelece mecanismos, critérios e valores da cobrança pelo uso da água bruta de domínio do estado da Paraíba, a partir de 2008 e dá outras providências. Diário Oficial do Estado da Paraíba, João Pessoa, PB, 19 mar. 2010.

PARAÍBA. Governo do Estado. SERHMACT - Secretaria de Estado dos Recursos Hídricos, do Meio Ambiente, e da Ciência e Tencologia, CERH - Conselho Estadual de Recursos Hídricos.
Resolução no 11, de 13 de junho de 2011. Dá nova redação e acrescenta dispositivos à Resolução nº 07, de 16 de julho de 2009, que estabelece mecanismos, critérios e valores da cobrança pelo uso da água bruta de domínio do estado da Paraíba, e dá outras providências. Diário Oficial do Estado da Paraíba, João Pessoa, PB, 30 jun. 2011a.

PARAÍBA. Governo do Estado. SERHMACT - Secretaria de Estado dos Recursos Hídricos, do Meio Ambiente, e da Ciência e Tencologia. CERH - Conselho Estadual de Recursos Hídricos. Resolução no 12 , de 13 de junho de 2011. Encaminha à Casa Civil do Governador proposta de Decreto que regulamenta o uso de água bruta de domínio do Estado, e dá outras providências. Diário Oficial do Estado da Paraíba, João Pessoa, PB, 30 jun. 2011b.

PARAÍBA. Governo do Estado. Decreto no 33.613, de 14 de dezembro de 2012. Regulamenta a cobrança pelo uso da água bruta de domínio do Estado da Paraíba, prevista na Lei no 6.308, de 02 de julho de 1996, e dá outras providências. Diário Oficial do Estado da Paraíba, João Pessoa, PB, 16 dez. 2012.

PERKINS, P. E. Public participation in watershed management: International practices for inclusiveness. Physics and Chemistry of the Earth, v. 36, n. 5-6, p. 204-212, 2011. http://dx.doi.org/10.1016/j. pce.2010.02.004.

PORTUGAL. Ministério do Ambiente e Recursos Naturais. DecretoLei n ${ }^{\circ} 45$ de 1994. DR 44/94 SÉRIE I-A de 1994-02-22. Regula o processo de planeamento de recursos hídricos e a elaboração e aprovação dos planos de recursos hídricos. Lisboa, 1994.

PORTUGAL. Ministério do Ambiente e Recursos Naturais. Lei n 58 de 29 de Dezembro de 2005. Aprova a Lei da Água, transpondo para a ordem jurídica nacional a Directiva no 2000/60/ CE, do Parlamento Europeu e do Conselho, de 23 de Outubro, e estabelecendo as bases e o quadro institucional para a gestão sustentável das águas. Lisboa, 2005.

PORTUGAL. Ministérios das Finanças e da Administração Pública e do Ambiente, do Ordenamento do Território e do Desenvolvimento Regional. Portaria 394 de 5 de Junho de 2008. Aprova os Estatutos da Administração da Região Hidrográfica do Norte, I. P., os Estatutos da Administração da Região Hidrográfica do Centro, I. P., os Estatutos da Administração da Região Hidrográfica do Tejo, I. P., os Estatutos da Administração da Região Hidrográfica do Alentejo, I. P., e os Estatutos da Administração da Região Hidrográfica do Algarve, I. P. Diário da República, Lisboa, n. ${ }^{\circ}$ 108/2008, Série I. 5 jun. 2008a.

PORTUGAL. Ministérios das Finanças e da Administração Pública e do Ambiente, do Ordenamento do Território e do Desenvolvimento Regional. Portaria 394 de 5 de Junho de 2008. Aprova os Estatutos da Administração da Região Hidrográfica do Norte, I. P., os Estatutos da Administração da Região Hidrográfica do Centro, I. P., os Estatutos da Administração da Região Hidrográfica do Tejo, I. P., os Estatutos da Administração da Região Hidrográfica do Alentejo, I. P., e os Estatutos da Administração da Região 
Public participation for bulk water charge: Paraíba River Basin Committee (Brazil) and Alentejo Hydrographic Region Council (Portugal) cases study

Hidrográfica do Algarve, I. P. Diário da República, Lisboa, n. ${ }^{\circ}$ 108/2008, Série I. 5 jun. 2008b.

PORTUGAL. Ministério do Ambiente, do Ordenamento do Território e do Desenvolvimento Regional. Decreto-lei 97 de 2008. Estabelece o regime económico e financeiro dos recursos hídricos. Diário da República, Lisboa, n. ${ }^{\circ}$ 111/2008, Série I. 11 jun. 2008c.

PORTUGAL. Ministério da Agricultura, do Mar, do Ambiente e do Ordenamento do Território. Decreto Lei no 130 de 22 de junho de 2012. D.R. I Série, 120 3109-3139. Procede à segunda alteração à Lei n. ${ }^{\circ}$ 58/2005, de 29 de dezembro, que aprova a Lei da Água, transpondo a Diretiva n. ${ }^{\circ}$ 2000/60/CE, do Parlamento Europeu e do Conselho, de 23 de outubro, e estabelecendo as bases e o quadro institucional para a gestão sustentável das águas. Diário da República, Lisboa, 22 jun. 2012.

REED, M. S. Stakeholder participation for environmental management: a literature review. Biological Conservation, v. 141, n. 10, p. 2417-2431, 2008. http://dx.doi.org/10.1016/j.biocon.2008.07.014.

REIS, D. I.; QUEVEDO, D. M.; NAIME, R. H. Gestão de recursos hídricos: panorama mundial, brasileiro e desafios institucionais. In: SIMPÓSIO BRASILEIRO DE RECURSOS HÍDRICOS, 20., 2013, Bento Gonçalves. Anais... Porto Alegre: ABRH, 2013. Available from: < http://www.abrh.org.br/xxsbrh/>. Access on: 10 sept. 2014.

RIBEIRO, M. A. F. M. Participação pública em gestão de recursos hídricos: uma análise do caso paraibano. 2011.187 f. Dissertação (Mestrado em Engenharia Civil e Ambiental) - Universidade Federal de Campina Grande, Campina Grande, 2011.

RIBEIRO, M. A. F. M.; BRAS, O. R.; VARANDA, M. P. RIBEIRO, M. M. R.; BENTO, S. I. C. A participação pública na construção da taxa de recursos hídricos: os casos das regiões hidrográficas do Alentejo e do Algarve. In: CONGRESSO IBÉRICO DE GESTÃO E PLANEAMENTO DA ÁGUA, 8., 2013, Lisboa. Anais... Lisboa: Fundación Nueva Cultura del Agua, 2013.

ROWE, G.; FREWER, L. Public participation methods: a framework for evaluation in science. Technology and Human Values, v. 25, n. 1, p. 3-29, 2000. http://dx.doi.org/10.1177/016224390002500101.

ROWE, G.; MARSH, R.; FREWER, L. J. Evaluation of a deliberative conference in science. Technology and Human Values, v. 29, n. 1, p. 88-121, 2004. http://dx.doi.org/10.1177/0162243903259194.

THOMAS, J. Public involvement and governmental effectiveness: a decision-making model for public managers. Administration
\& Society, v. 24, n. 4, p. 444-469, 1993. http://dx.doi. org/10.1177/009539979302400402.

TIPPETT, J.; HANDLEY, J. F.; RAVETZ, J. Meeting the challenges of sustainable development - a conceptual appraisal of a new methodology for participatory ecological planning. Progress in Planning, v. 67, n. 1, p. 9-98, 2007. http://dx.doi.org/10.1016/j. progress.2006.12.004.

VASCONCELOS, L.; DUARTE, L.; VEIGA, B. G. A.; VALARIE, P.; CASIMIRO, I.; CUAMBA, B.; SAYAGO, D.; SOBRAL, M. C.; OLIMPIO, M. Ecossistemas, Água e Participação - estratégias nas políticas de recursos hídricos do Portugal, Brasil e Moçambique. Revista Online da Sociedade Portuguesa de Ecologia, v. 2, p. 29-41, 2011. Available from: < http://speco.fc.ul.pt/revistaecologia_2.html>. Access on: 14 aug. 2015.

VEIGA, B. G. A. Participação social e políticas públicas de gestão das águas: olhares sobre as experiências do Brasil, Portugal e França. 2007. 320 f. Tese (Doutorado em Desenvolvimento Sustentável) - Universidade de Brasília, Brasília, 2007.

VEIGA, L. B. E.; MAGRINI, A. The Brazilian water resources management policy: fifteen years of success and challenges. Water Resources Management, v. 27, p. 2287-2302, 2013.

WANDERSMAN, A. A framework of participation in community organisations. The Journal of Applied Behavioral Science, v. 17, n. 1, p. 27-58, 1981. http://dx.doi.org/10.1177/002188638101700103.

YANG, X.; XU, J.; DONZIER, J.; NOEL, C. A comparison of the water management systems in France and China. Frontiers of Environmental Science \& Engineering, v. 7, n. 5, p. 721-734, 2013. http://dx.doi.org/10.1007/s11783-013-0550-z.

\section{Authors contributions}

Maria Adriana de Freitas Mágero Ribeiro: Work Conception, performed bibliographic research, data collection and treatment, data analysis, results discussion and article writing.

Márcia Maria Rios Ribeiro: Work Conception, data analysis, results discussion and article wrting.

Marta Pedro Varanda: Work Conception, results discussion and article wrting. 